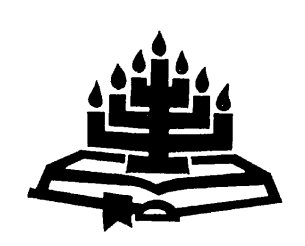

\title{
Traditions of martyrdom in the Ignatian Letters
}

\author{
S. Fuhrmann
}

Westfälische Wilhelms-Universität

Münster

Unit for Reformed Theology

Potchefstroom Campus

North-West University

POTCHEFSTROOM

E-mail: sebastian.fuhrmann@uni-muenster.de

\begin{abstract}
Traditions of martyrdom in the Ignatian Letters

The letters of Ignatius represent one of the key texts for the emergence of martyrdom during the second century $A D$ in Christianity. This article is concerned with the question whether Ignatius contributed to a "theology of martyrdom" or whether he rather relied on previous traditions. The author argues, by undertaking an analysis of certain pragmatics and semantics, that the motif of martyrdom is solely used to buttress Ignatius' claim for authority among his intended addressees by referring to an understanding of martyrdom that has its roots in the New Testament. An identification of the author of the letters with a historical martyr is regarded as unlikely.
\end{abstract}

\section{Opsomming}

\section{Martelaarskapstradisies in die Ignatiusbriewe}

Die Ignatiusbriewe verteenwoordig een van die sleuteltekste vir die opkoms van martelaarskap in die Christendom in die tweede eeu n.C. Hierdie artikel wil vasstel of lgnatius bygedra het tot 'n "teologie van martelaarskap", en of hy bloot steun op vorige tradisies. Die outeur se argument, gebou op die ontleding van pragmatiek- en semantiekfasette, kom daarop neer dat lgnatius die martelaarskapsmotief gebruik om sy aanspraak op gesag onder sy geadresseerdes te versterk deur te verwys na 'n verstaan van martelaarskap waarvan die wortels op die Nuwe Testament teruggaan. Dit lyk onwaarskynlik dat die outeur van die briewe self ' $n$ historiese martelaar was. 


\section{Introduction}

Among the writings that have been passed down from the second century AD the seven letters of Ignatius of Antioch are still a matter of dispute among scholars. Their dating varies from before AD 117 (e.g. Zahn, 1873) till approximately AD 180 (Barnes, 2008; cf. Löhr, 2009: 108 ff.; Holmes, 2007:170-173), often but not necessarily related to the question of authenticity. Furthermore, there is neither thorough certainty with regard to the extent, although the so-called middle recension is widely acknowledged as original, nor as to the order, of the latter. This article is concerned with martyrdom in the Ignatian Letters, in particular with the question whether Ignatius - I take this name for the author of the seven letters that are usually regarded as authentic - develops a sort of genuine theology of martyrdom in his writings and, if so, what traditions he bases it on. This concern is combined with the question of the pragmatics of the martyrdom passages.

The letters assigned to Ignatius of Antioch ${ }^{1}$ suggest that they were written by a bishop from Asia Minor on his way from Antioch to Rome as a prisoner, on two stops, which his transport made: in Smyrna, and in Troas. ${ }^{2}$ There are, however, hardly any direct hints within the writings that would allow one to fix the date of origin, 3 neither is there relevant Lokalkolorit. 4 Two of the names mentioned, besides Jesus, Peter, and Paul, are known from other sources: Onesimus, whom Ignatius labels as the bishop of Ephesus (IgnEph

1 The Ignatian Letters are quoted, if not marked otherwise, from Holmes (2007:182-271).

2 The letters to the Ephesians (IgnEph), to the Magnesians (IgnMagn), to the Trallians (IgnTrall) and to the Romans (IgnRom) are supposed to be from Smyrna; the letters to the Philippians (IgnPhil), to the Smyrneans (IgnSm) and to Polycarp (IgnPol) from Troas.

3 Beside the notions in Eusebius of Pliny the Younger's letter to the emperor Trajan (h.e. 3.33.1-3; 1973:276-279) in connection with these of Polycarp, Papias and Ignatius (h.e. 3.36), which led to the early dating, we have a terminus post quem the New Testament writings, and ante quem - for verse 13:2 in the epistle of Polycarp to the Philippians could be an interpolation Irenaeus (adv. haer. 5.28.4; here, however, without a mention of a name, just

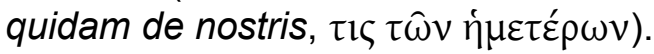

4 This is the case even if there are discernible opponents in the respective churches, see Uebele (2001), or Meinhold (1979). 
1:3 et al. $)^{5}$ and Polycarp, bishop of Smyrna (IgnPol), a prominent martyr. These uncertainties add to those mentioned above.

Recent debate has raised the question of the authenticity of the Ignatian Letters again (esp. Hübner, 1997 and Schnithals, 2009). I am quite convinced, too, that the Ignatian correspondence is a piece of literature, and that the author is not the same as the Ignatius who was convicted, if that person ever existed. With regard to the martyrdom my main argument consists of the fact that we have two accounts of two famous bishops in the second century who suffered martyrdom, Ignatius and Polycarp: Ignatius alludes, as I think, to Polycarp's martyrdom (see below), while on the other hand Ignatius is not mentioned in the Martyrium Polycarpi (MPol) at all. The historical question, however, is not the focus here; this article is not concerned with the events (cf. Trevett, 1989), but with the theological interpretation of the voluntary death as such; that is, the focus falls on the pragmatic aspects of martyrdom within the writing. However, since it will be shown that Ignatius' references to martyrdom are solely intended to support and to validate his theological statements concerning mainly unity and obedience to office-bearers in the respective churches, in particular to the bishops, a further argument for the fictitious character of the Ignatian Letters is provided.

\section{Pragmatic aspects of the utterances concerning martyrdom in the Ignatian Letters.}

As mentioned above, the plot of the narrative suggests that the letters were from the pen of a convict, sentenced to death, on the way to his execution. The letters, therefore, have to be regarded as final words of a testamentary character (Stoops, 1987:176 ff.). This is, however, one of the few points which is certain. Besides the uncertainties concerning the transmission of the text - not to mention the questions arising out of the different recensions - it is the language of the Antiochenean that complicates the whole matter of assigning the statements to the subject area of martyrdom. The asianic style of the author (Perler, 1949:57-71; Riesenfeld, 1961: 314-318; Brent, 2006), peppered moreover with plenty of phrases belonging to the topos of modesty, hinders the interpreter from deciding whether this humble speech is used in terms of rhetoric or

5 The possibility cannot be ruled out that the former slave named in Paul's letter to Philemon, mentioned in Colossians $4: 4$ as well, is meant by this. Because Colossians was regarded by Marcion as written in Ephesus (cf. Preuschen, 1910:87), and Ignatius would refer to the same tradition. 
argument. One has to assume a combination of both. Additionally, as often stated by scholars, 6 there is no thematic disposition within the letters. Whether this is an expression of unknown individuality and informality (Norden, 1915:510), however, might be questioned. Provided that the order of letters conveyed by Eusebius (h.e. 3.36) is the one the author intended - although, as is well known, there is no manuscript that provides the order Eusebius suggests (Lightfoot, 1889a:73-109; 1889b:1-11; Holmes, 2007:175-177) - there are certain lines of thought and a sort of development of ideas. Furthermore, in Polycarp's letter to the Philippians 13:2 (cf. Holmes, 2007: 280-297) there might be an indication that the Ignatian Letters were intended to be read as a collection (Hübner, 1997:66). In terms of this possibility I will examine whether the Ignatian correspondence can be read as if it were an epistolary novel (for the concept, cf. Glaser, 2009:29-167).

A first glance at the compilation of the allusions to the Ignatian martyrdom indicates an unequal distribution of these within the individual letters. The readers receive their information piece by piece (as is typical of epistolary novels, cf. Glaser 2009:44: Enthüllungsdramatik), starting with a short introduction in IgnEph 1:2. While there is no elaborated reference to the martyrdom in the letter to the Magnesians, in 5:2 the letter to the Trallians provides an important hint as to the function of this martyrdom, in IgnTral 9:2; 10; furthermore, we find the first evidence for this function with respect to the Christological, antidocetic argument. In the letter to the Romans the allusions that had been loosely spread up to that point are bundled: in terms of a dramatic composition we find a sort of climax here. The whole letter is dedicated to the topic of martyrdom. The collection reaches its third climax in the letter to Polycarp.

Therefore one may observe a certain arrangement that could lead to the conclusion that the letters were designed as a collection; given, as mentioned above, that Eusebius provides the intended order.

\subsection{A first approach: the confession-like paragraphs}

Within the letters Von Campenhausen (1972:246 ff.; cf. Hübner, 1997:53) identified a total of eight paragraphs of varying length, that

6 The disposition of the letters is "alles andere als straff und klar; Ignatius legt seine Gedanken nicht in fortschreitender logischer Entwicklung sondern in einer Vielfalt von Aspekten dar, bei denen es gleichgültig ist, mit welchem man beginnt und aufhört" (Vielhauer, 1975:549). 
express christological statements in the manner of a regula fidei. These paragraphs are to be found in IgnEph 7:2; 18:2; IgnMagn 8:2 (though not christological); 8:11; IgnTrall 9:1f; IgnPhil 9:2; IgnSmyrn 1:1f; and IgnPol 3:2. At first glance it is obvious that Romans is the only one of the Ignatian Letters that does not contain any of those texts. On the narrative level, which is the suggested historical one as well, this can be explained by Ignatius' ignorance of the Roman Church. Therefore he does not teach, but only pleads that they do not prevent his martyrdom. Historically this seems to be highly unlikely. The respective confession-like paragraphs are not situational or composed with regard to the respective addressees; in addition, they are well-nigh interchangeable with each other. In addition one would wonder why lgnatius, otherwise not reluctant to teach and to exhort, was so reserved on this score in Romans. The lack of any indoctrination in Romans rather points to a compositional intention. Romans, as mentioned above, is reserved for the explication of the impact of the martyrdom.

Another observation can be made with respect to the confession-like paragraphs. Most of these passages are located in the immediate vicinity of statements concerning martyrdom, namely IgnMagn 8:2 with reference to the martyrdom of the prophets, IgnMagn 11 with 12; IgnTrall 9:1-2 with 10; IgnSmyrn 1:1f. with 3 and 4 and IgnPol $3: 2$ with $2: 3$. That is, five out of eight of the central confession-like texts are related to utterances concerning martyrdom. In other words, Ignatius placed the references to his martyrdom together with his highly significant theological statements.

How is this relation to be understood?

\subsection{The authority of martyrs}

Hübner (1997:66-70) refers to the specific authority inherent in the martyr because of his capicity for special knowledge (gnosis) by means of the spirit. This tradition is vivid since the time of the New Testament authors and of the traditions they relied on, and the functionalisation of the martyrdom in the Ignatian Letters seems to have one of its roots in these traditions.

Three groups in early Christianity were regarded as being able to proclaim truth with the authority of the Spirit: apostles, prophets, and martyrs. There was enough historical consciousness among the second century churches to realise that in the course of time the 
possibilities of receiving an autograph boasting apostolic authority tended to cease. 7 To a considerable degree apocalyptic prophecy lost its reputation and authority as well, at the latest on the appearance of Montanism. But even if one assumes the composition of the Ignatian Letters at an earlier stage, one finds this tendency as early as the Shepherd of Hermas. The particular importance assigned to the witness of a martyr is rooted in the New Testament, based on two foundations. Firstly, in the logion concerning persecution in $Q$ (Luke 21:13-15; Matt. 10:19-20). In court, Christians can rely on the Spirit given to them by the Father (Matt. 19:20) or Christ respectively (Luke 21:15), so that their opponents will not be able to withstand them.

The second is to be found in the account of the martyrdom of Stephen. In Acts 6:10 one reads about his opponents that "they

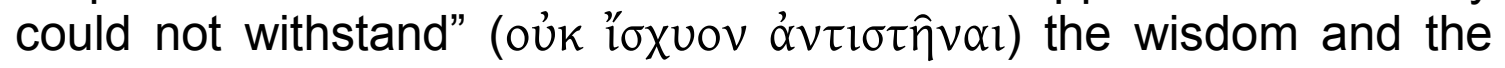
Spirit with which he spoke, which clearly is an intra- (resp. inter)-

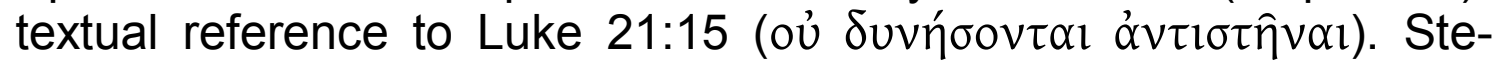
phen was filled with the Spirit (Acts 6:5), did "wonders and signs" (Acts 6:8) and "his face was the face of an angel" (Acts 6:15), a description which later became a topos in Christian accounts of martyrdom. Subsequent to his sermon it is stated (Acts 7:55-58) that he was "filled with the Holy Spirit" and "gazed into heaven and saw the glory of God and Jesus standing at the right hand of God" (Acts 7:55). He utters his vision (Acts 7:56), the crowd covers its ears (Acts 7:56) and begins to stone him (Acts 6:58).

Immediately before his violent death Stephen perceives a vision of the heavenly throne. The dramatic character of the scene reveals that it is impossible for the martyr to communicate his/her vision. It becomes clear that within the Ignatian Letters - by means of the narrative setting - there is the possibility of extending the short period between conviction and execution as long as was necessary. Ignatius becomes a "dead man walking", who is enabled to teach and make his dispositions with the full authority of the dying martyr. Another witness for the combination of the particular dignity of the martyrs with a special closeness to God as well is provided in Revelations 20:4, where the apocalypticist envisions the souls of the martyrs as being in close proximity to the throne (cf. Rev. 3:21).

7 Cf. Tertullian (De Beptismo 17.5): The presbyter, who passed the acts of Paul, together with 3 Corinthians, was detected as a forger and lost his office. (Cf. also Hübner, 1997:68.) 
Within the writings of the apostolic fathers these motifs reappear. Polycarp, for instance, is characterised as a reliable prophet in MPol 16:2. Although not explicitly mentioned, it is obvious that his reliability is based on his martyrdom: "every word that went out of his mouth either has been or shall yet be accomplished".

The Shepherd of Hermas (cf. Holmes, 2007:454-685) is of particular interest concerning the relation between martyr and prophet. Hermas, who depicts himself as a prophetic visionary, in his third vision is confronted with the fact that the martyrs are superior to him in terms of dignity, as he is told by the old woman: "The place to the right is for others who have already pleased God, and have suffered for His name's sake; and you have yet much to accomplish before you can sit with them." (HermVis 3.1.9; cf. HermVis 3.5.2; HermSim 8.3.6-7; HermSim 9.28.1-6, 8.)

Against this background - the special function of the testimony and the prophetic vision of a martyr - a majority of references to martyrdom in the Ignatian correspondence can be understood by means of the pragmatic intention of the author. On the assumption that the Ignatian Letters were intended to be read as a collection, this concerns all those statements which are directly related to authoritarian indoctrination, regarding in particular the subordination under the Bishop and the presbyters as well as the admonitions to unity within the churches. Those passages are IgnEph 3.1, IgnMagn 12.1, IgnTrall 4.2; 5.2; 12.2, IgnPhil 7.2; IgnSmyrn 9.2; 10.1 and possibly IgnPol 2.3. This relation is to be found explicitly for the first time in IgnTrall 5.2:

For I myself, though I am in chains and can comprehend heavenly things, the ranks of the angels and the hierarchy of principalities, things visible and invisible - despite all this I am not yet a disciple.

The reference to martyrdom in IgnRom 2.2 , subsequent to the antithetic formulation "word of God" - "mere voice" in Romans 2:1 (for the terminology, cf. Schoedel, 1985:170-171) follows the similar line of thought. Ignatius here is "contrasting an authentic and inauthentic witness to God" (Schoedel, 1985:171) - the authenticity, however, derives from Ignatius' affirmation as a martyr. The same notion underlies his statements in IgnRom 3 - "when he will be no longer vis-

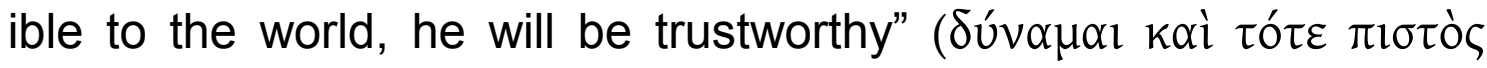

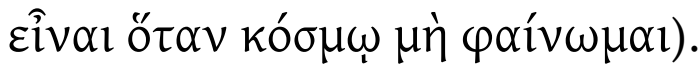




\subsection{The antidocetic statements}

Ignatius' polemics towards docentic positions are validated by the authority of a Spirit filled martyr, too, but the reference to the martyrdom itself now fulfils an argumentative function of its own, insofar as the author links his expected suffering in the flesh to Christ's fleshly appearance. In the same way as Christ is the typos of his suffering, Ignatius' martyrdom is the proof of Christ's suffering in the flesh.

This may be illustrated with regard to IgnTrall 9 and 10 . Although the argumentation is rather short, the reference to martyrdom is nonetheless obvious. The argument reminds one of, and is probably an allusion to, Paul's reasoning in 1 Corinthians 15:

\begin{tabular}{|l|l|}
\hline $\begin{array}{l}\text { 1 Cor. 15:14s: } \\
\text { But if }\end{array}$ & $\begin{array}{l}\text { IgnTr 10:1 } \\
\text { But if }\end{array}$ \\
$\begin{array}{l}\text { Christ is not risen } \\
\text { [cf. 1 Cor. 15:12: as some among you say] } \\
\text { then our preaching is empty } \\
\text { and your faith is also empty. }\end{array}$ & $\begin{array}{l}\text { as some atheist (that is, unbelievers) say, } \\
\text { suffered in appearance only } \\
\text { (while they exist in appearance only!), } \\
\text { why am I in chains? } \\
\text { And why do I want to fight with wild beasts? } \\
\text { If that is the case, } \\
\text { I die for no reason; } \\
\text { what is more, I am telling lies about the Lord. }\end{array}$ \\
$\begin{array}{l}\text { Yes, and we are found false witnesses of } \\
\text { God ... }\end{array}$ &
\end{tabular}

While Paul argues with the authority of his apostolate and the

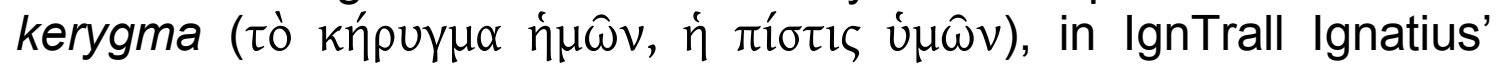

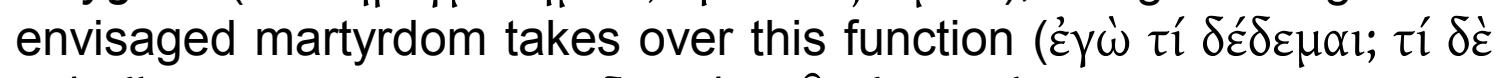

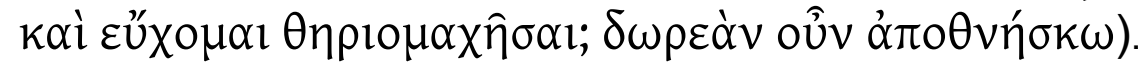

The antidocetic argumentation is explicated with reference to the martyrdom in IgnSmyrn 3; 4.2. Ignatius first argues with respect to the martyrdom of Peter and those with him - a tradition already to be found in John, and later on further developed in pertinent works (cf. Bauckham, 1992) - stating, that their martyrdoms were motivated by Christ's appearance in the flesh (IgnSmyrn 3.1-3). Thereafter he turns to his own martyrdom as a proof for his antidocetic doctrine: he himself by suffering in the flesh provides evidence that Christ suffered in the flesh too (IgnSmyrn 4.2).

\subsection{Martyrdom and apostolic authority}

Both the last examples illustrate the tendency of Ignatius to use the account of his martyrdom in order to compare his authority to the 
authority of the apostles and to approximate both these authorities (Stoops, 1987:168-172). In his first letter, IgnEph, this issue is raised for the first time, yet without explicit consequences. Ignatius simply compares himself to Paul by expressing the wish to be found in his

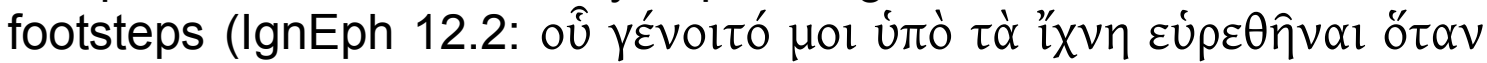
$\theta \varepsilon \circ \hat{v} \varepsilon \pi \iota \tau u ́ x(\omega)$. The reader of course is supposed to perceive that Ignatius by means of is suffering is already imitating Paul - and his teachings might therefore be regarded as authoritative as Paul's. What was only alluded to in IgnEph is explicated in IgnRom 4.3. Together with his typical topos of modesty (cf. Hagenbichler, 1992) he compares himself to Peter and Paul, implying that his sufferings will enable him to gain the same freedom, that is - authority.

I do not give you orders like Peter and Paul: they were apostles, I am a convict; they were free, but I am even now still a slave. But if I suffer, I will be a freedman of Jesus Christ and will rise up free in him.

\subsection{The idea of imitatio Christi}

Although an explicit reference to the idea of imitatio is only to be

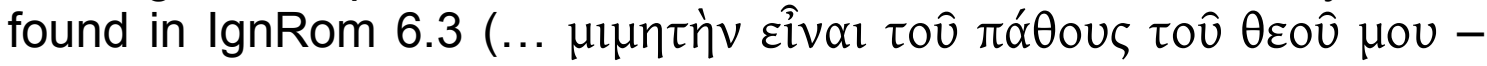
allow me to be an imitator of the suffering of my God), and a lucid allusion in IgnEph 10.2, it is in general possible to consider the whole setting of the Ignatian depiction of his transport towards Rome as an imitation of Jesus. By constantly referring to his humble status (see below), and thereby implying that his full authority and position as a disciple will only come to the fore after enduring his martyrdom, he is imitating a narrative of Christ's dwelling on earth, as developed for instance in the Gospel of Mark as well. Be that as it may, the line is not drawn explicitly in the Ignatian Letters, at least not as clearly as the parallels drawn with Paul (and Peter).

\section{Semantic aspects of the utterances concerning martyrdom}

In the lines above we have intended to show that most of the evidence for a martyrdom related theology in the Ignatian Letters functions to support other, non martyrological lines of thought, in particular the Ignatian teachings concerning unity and his reflections on the ministry. It is permissible, therefore, to conclude from the pragmatic function of the martyrdom topic that martyrdom itself is not a thematic issue for the Ignatian Letters. 
One should, of course, mention a caveat, for there are two concepts that might prove otherwise. In the following paragraph I am therefore

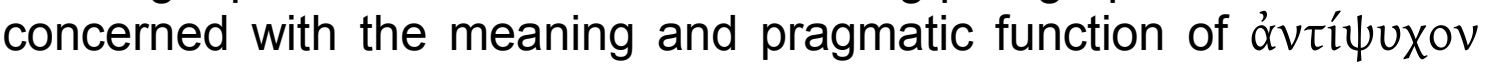
and $\pi \varepsilon \rho i ́ \psi \eta \mu \alpha$. If these concepts referred to a sort of atoning, expiating, or vicarious, thus cultic, sacrifice of the martyr in terms of an effective death, one would have a strong indication of a martyrdomrelated theology in the Ignatian corresondence. The evidence, however, proves otherwise.

\section{$3.1 \pi \varepsilon \operatorname{li}_{\psi} \eta \mu \alpha$}

Reading translations of IgnEph 8.1 and 18.1, one faces obvious

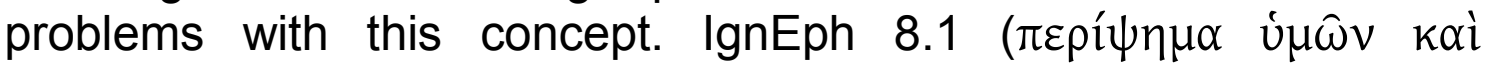

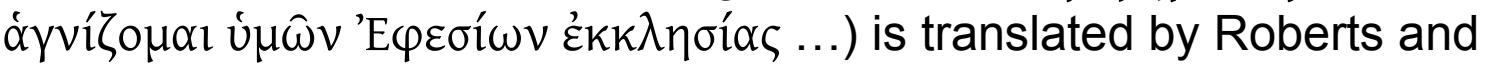
Donaldson (1973): "I am far inferior to you, and require to be sanctified by your Church of Ephesus", while Holmes (2007) offers here: "I am a humble sacrifice for you and I dedicate myself to you Ephesians ..." (similarly Schoedel, 1985:63). In IgnEph 18.1

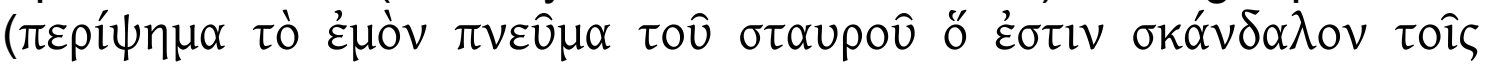

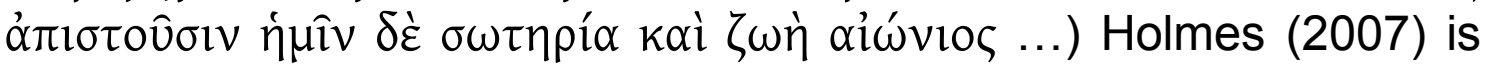
suggesting "My spirit is a humble sacrifice for the cross ...", while in the Ante-Nicene fathers this is rendered: "Let my spirit be counted as nothing for the sake of the cross ...". The explanation lies within the ambiguity of Ignatius' humble pathos, but also in the multifaceted use and meaning of the noun itself. 8

The term is most likely to be interpreted as an exponent of the extensive use Ignatius makes of the topos of humility. 9 The main indicator of this is the context within which the concept is placed.

See Stählin (1959:83-92): Derived from $\psi \alpha ́$ ' $\omega$, the noun in the non-metaphorical sense denotes "offscouring" et cetera; furthermore, the "means of scouring and cleaning, in particular a washcloth or a towel". In the metaphorical sense it is supposed to indicate "a religious purifier, a sin offering, a scapegoat". The metaphorical dimension of $\pi \varepsilon \rho i ́ \psi \eta \mu \alpha$, however, is documented quite late: the lexicographers Photius and Suidas provide an entry s.v., where the term is treated in relation to the idea of the $\varphi \alpha \rho \mu \alpha \kappa o ́ s$ - "the personified remedy, the human medicine". Only once is $\pi \varepsilon p i ́ \psi \eta \mu \alpha$ to be found in the LXX, Tob 5:19, once in the NT, 1 Corinthians 4:19 (here: offscouring), within the apostolic fathers in Barn 4:9; 6:5, where it is clearly humble speech. The only evidence for a use as ransom is Tob 5:19. See also Moulton and Mulligan (1930: s.v.). Lampe (1961: s.v.), however, states no metaphorical sense.

$9 \quad$ For instance IgnEph 2.2; 3.1; 12.1; 21.2; IgnMagn 11.1; $12.1 ; 14.1$; IgnRom 9.1; IgnSm 11.1, et cetera. 
Ignatius seems to play with the ambiguity of $\pi \varepsilon p i ́ \psi \eta \mu \alpha$ in IgnEph

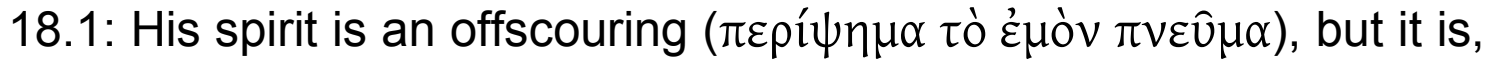
on the other hand, scraped off the cross of Christ, which is characterised as giving salvation and life. Ignatius thus formulates his own theologia gloriae in the words of a theologia crucis: Only those who do not understand the $\sigma \kappa \alpha$ v $v \alpha \alpha \lambda o v$ of the cross could regard its offscouring as rubbish. To be an offscouring, however, means that Ignatius is a partaker of salvation, counted among those who will be saved. If there is no indication to assume a meaning of cultic sacrifice for $\pi \varepsilon p i ́ \psi \eta \mu \alpha$ in IgnEph 18.1 we have a strong argument not to assume it for Ephesians 8.1 either. Although $\alpha \gamma v i ́ \zeta \omega$

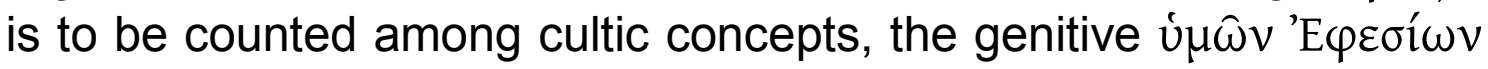
$\varepsilon \kappa \kappa \lambda \eta \sigma i ́ \alpha \varsigma$ indicates that Ignatius is again teasing out the oscillating ideas of separation and sanctification.

\section{2 ỏv $\tau i ́ \psi v \times 0 v$}

An interpretation of $\pi \varepsilon \rho i ́ \psi \eta \mu \alpha$ as a cultic term, however, stands and falls with the meaning of $\alpha v \tau i ́\} v x o v$. To explore the meaning of the concept, we will firstly analyse its place within the Ignatian Letters. Secondly, we will turn to the concept itself in order to eventually elaborate the traditions by which Ignatius was possibly influenced into using the term.

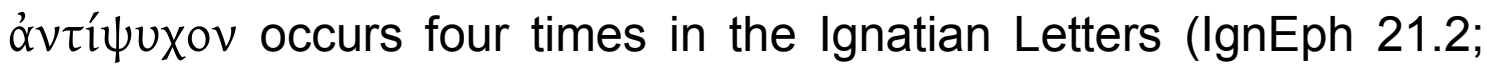
IgnSm 10.2; IgnPol 2.3; 6.1), so that the term could be regarded as framing the whole collection. On the other hand, in IgnEph and

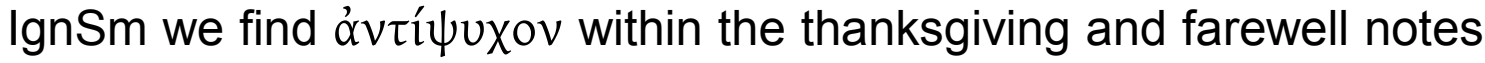
at the end of the letters, not concerned with any argumentative issues. In IgnPol $2.3 \alpha v \tau i$ 'i uxov is to be found amidst exhortations and recommendations for Polycarp's administrative and pastoral tasks, while in IgnPol 6.1 Ignatius again turns to the congregation of Polycarp. We begin with Polycarp 2.3.

The letter addressed to the Smyrnean Bishop is, in its first five chapters, concerned with the behaviour of a bishop. The passage containing $\alpha v \tau i$ íxov is quite in the middle of this context, emphasising the impact of Polycarp's ministry by encouraging him with reference to the prospect of eternal life.

This passage could provide an argument for a late dating of the Ignatian Letters, since they seem to presuppose the martyrdom of Polycarp. For Ignatius touches on the kalpó the actual situation (Schoedel, 1985:264), where Polycarp is still 
needed for the sake of the church. Against the backcloth of Plato's and Aristotle's prominent considerations about killing oneself - and their conclusion, "that the question of life or death must be evaluated finally in light of an individual's civic responsibilities" (Droge \& Tabor, 1992:23) - this might be an allusion to his later martyrdom. In any case, Ignatius - employing nautical and athletic metaphors (cf. Perler, 1949) - stresses the necessity of endurance, reminding Polycarp of the prize - incorruptibility and eternal life. Subsequent to these exhortations Ignatius states (IgnPol 2:3):

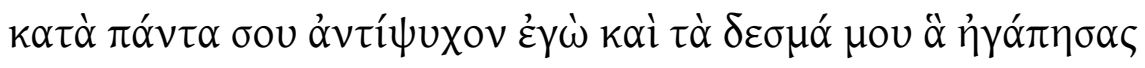

In every respect I am an ỏvtíquxov [Holmes: a ransom] and my chains as well, which you loved.

When, however, persistence and determination lead to an adequate extramundane compensation - what is the role of Ignatius' martyrdom within this context? The fact that Ignatius is referring to his chains as also being part of the $\alpha v \tau i$ í $u x o v$ reminds the reader of his explications of the connection between his martyrdom and Christ's dwelling in the flesh. Compensation for endurance and suffering is enabled by Christ's suffering. Ignatius' martyrdom is a

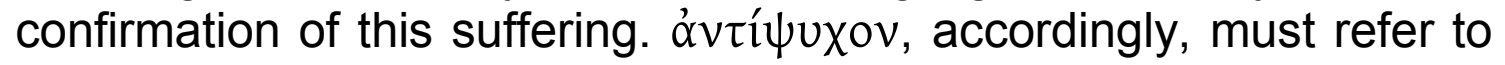
the function of the martyrdom as a warrant or even a pledge for those who did not benefit from the possibility - the kalpó $\varsigma$ - of suffering a martyr's death.

Even clearer is the message in IgnPol 6:1. Here Ignatius abruptly switches to the congregation, whose bishop had previously been appealed to. Ignatius demands attention to the bishop, which will be compensated for by divine attention. He proceeds:

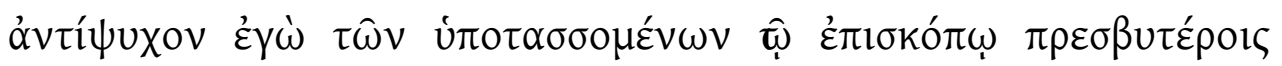

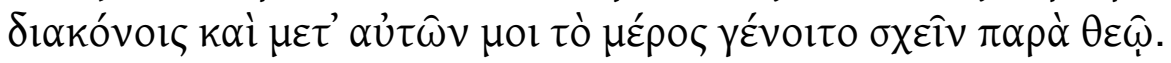

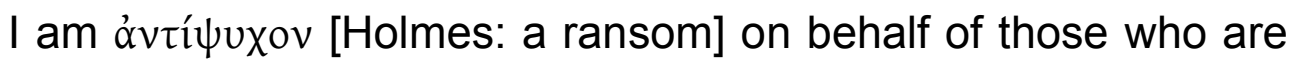
obedient to the bishop, presbyters, and deacons; may it be granted to me to have a place among them in the presence of God!

The intention is clear: for those who are obedient Ignatius provides a warrant that they will share with him his being present with God. Given that Ignatius, as a dead man walking, is already $\pi \alpha \rho \alpha \hat{\alpha} \theta \varepsilon \hat{\omega}$, the sense of $\alpha v \tau i ́ \psi v x o v$ as warrant or pledge is evident. 
A similar meaning can be supposed for both the other quotations in the concluding parts of IgnEph and IgnSm.

\subsubsection{The meaning of $\alpha \dot{v} \tau \tau^{\prime} \psi v x o v$ in other coeval sources}

Does our interpretation of $\alpha v \tau i ́\} v x o v$ fit its use in other coeval sources? Firstly, there is not even a handful of evidence for this noun before $A D 250$ or even $A D 300$ according to the Thesaurus linguae Graecae (TLG; 2010). The most prominent passage surely is 4 Maccabees, where it occurs twice, firstly in a prayer of Eleazar $6: 29$, secondly in the peroratio (17:21), where the martyrs' achievements were summarised. Both passages are quite similar. In 4 Maccabees 6:28 ff. Eleazar prays to God that the martyrs should be punished on behalf of the nation, that his blood may become the purification of the people ( $\kappa \alpha \theta \alpha$ ó $\sigma$ tov $\alpha \hat{v} \tau \hat{\omega} v)$, his life a ransom for

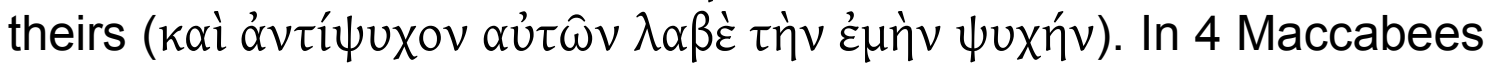
$17: 21$ it is stated that by means of their death the homeland was purified ( $\tau \dot{\eta} v \pi \alpha \tau \rho i \delta \alpha \kappa \alpha \theta \alpha \rho \imath \sigma \theta \hat{\eta} v \alpha l$ ), and that the martyrs have

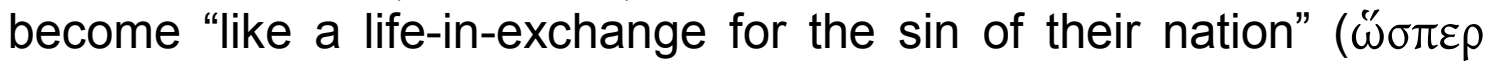

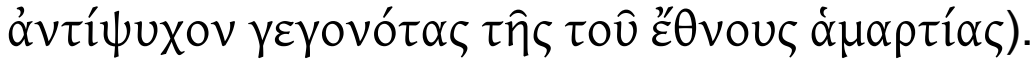

The terminology, in particular in the second quotation, is clearly

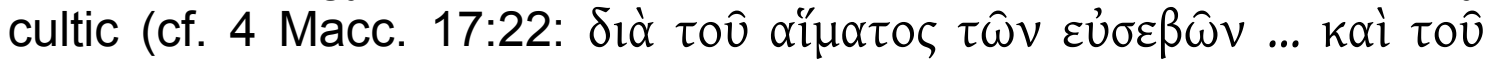

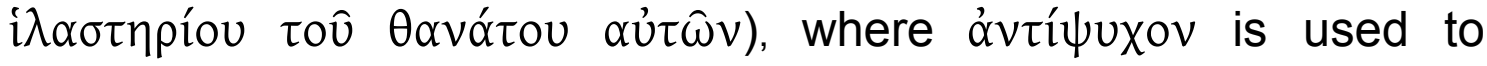
determine a sort of cultic sacrifice. The author of 4 Maccabees, however, applies the conjunction $̋ \sigma \pi \varepsilon \rho$, thereby indicating that the noun is used metaphorically. The death of the martyrs is depicted as a vicarious death with an effect on the whole nation. In the second example offered by Lucian (Lexiphanes 10.20), the term is used as

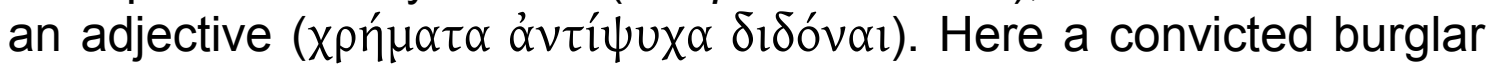

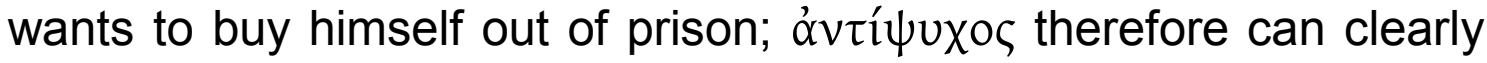
be rendered as ransom (perhaps bail).

The last example we have - before the term is commonly used by Eusebius in the way 4 Maccabees does ${ }^{10}$ - is to be found within Dio Cassius' Roman history (59:8.3), describing certain events after Caligula's recovery from a sickness. Two Roman citizens had promised under oath that they would give their lives if only Caligula

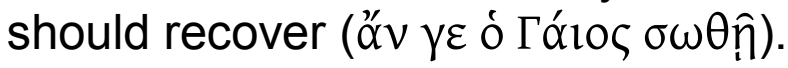

10 In Eusebius' works there are over 30 instances of the noun. In his

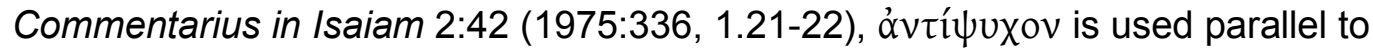

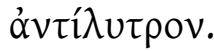


For these men, instead of the money which they hoped to receive from him in return for offering to give their lives in

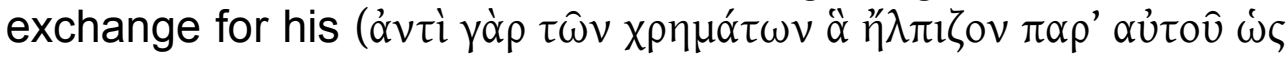

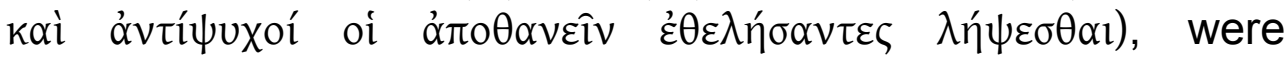
compelled to keep their promises, so as not to be guilty of perjury.

This last record sheds an interesting light on Ignatius' use of the noun. Obviously, the citizens intended to give their lives in case Caligula's course of illness was not positive. Since he recovered better than had been expected, they regarded their offer as not useful any longer and were expecting a reward for their devotedness. Although the vicarious character of $\alpha v \tau i$ $\psi v x$ x comes to the fore insofar as Caligula regarded their promise to give their life as a sort of remedy, the dimension of warrant or pledge is encountered as well, namely in the perspective of the two citizens. They regarded their offering as a last choice in case things had turned out worse.

The question arises: Is there any vicarious character in Ignatius' martyrdom?

Brent (2006:221-230), in his knowledgeable monograph on the relation between the Ignatian Letters and the second sophistic, interprets $\alpha v \tau i ́\} v \times 0 v$ (and $\pi \varepsilon \rho i ́ \psi \eta \mu \alpha$ ) in terms of the joint sacrifice of mystery cults in Asia Minor, an idea which, though appealing, is not covered by the terminology: ơ $v \tau i ́ \psi v x o v$ and $\pi \varepsilon p i ́ \psi \eta \mu \alpha$ do not occur in his quotations from relevant literature, while on the other hand Ignatius does not speak of $\sigma u v \theta v \sigma i \alpha$, which is a key term for Brent's whole construction. I, therefore, see no explanation for $\alpha \dot{\alpha} v i \dot{\psi} \psi v x \circ v$ in the Ignatian Letters in terms of a vicarious sacrifice. Its position within the concluding remarks of Ephesians and Smyrneans seems to buttress my assumption that the term functions as an edifying note, playing with the idea of his martyrdom as an offering for God and his message and doctrine as a remedy against discord.

\section{Final notes}

While there are questions remaining - in particular with regard to the relation between Ignatius' martyrdom and his allusions to the Eucharist - certain conclusions can be drawn.

- The Ignatian Letters do not provide a theology of martyrdom.

- There is neither an idea of an effective death in terms of a salvific effect for others; nor of an exemplum virtutis in order to convince 
non believers, as witnessed, for example by Tertullian (Apologeticum 50,14: Semen est sanguis Christianorum).

- Throughout the letters the idea of martyrdom is used in terms of pragmatics to buttress the authority of the teaching of Ignatius, regarding in particular subordination under bishop and presbyters. This subordination correlates with Ignatius' depiction of the heavenly realm, which he - as a "dead man walking" - was enabled to see.

- The authority of Ignatius as a martyr is therefore - according to the writings - comparable to apostolic authority.

- Furthermore, the martyrdom is used to support antidocetic arguments.

- The whole setting of the letters causes their authorship by the historical martyr Ignatius to be only a remote likelihood.

\section{List of references}

BARNES, T.D. 2008. The date of Ignatius. The expository times, 120:119-130.

BAUCKHAM, R.J. 1992. The martyrdom of Peter in Early Christian literature. Aufstieg und Niedergang der Römischen Welt II, 26(1):539-595.

BRENT, A. 2006. Ignatius of Antioch and the second sophistic. Tübingen: Siebeck.

DIO CASSIUS. 1924. Roman history. Trans. by E. Cary. London: Heinemann. (Loeb Classical Library, vol. 7.)

DROGE, A.J. \& TABOR, J.D. 1992. A noble death: suicide and martyrdom among Christians and Jews in antiquity. San Francisco: Harper.

EUSEBIUS. 1973. The ecclesiastical history. Trans. by J.E.L. Oulton. London: Heinemann. (Loeb Classical Library, vol. 2.)

EUSEBIUS. 1975. Der Jesajakommentar. Rev. by J. Ziegler. Berlin: AkademieVerlag. (Die Griechischen Christlichen Schriftsteller. TI. 9.)

GLASER, T. 2009. Paulus als Briefroman erzählt: Studien zum antiken Briefroman und seiner Christlichen Rezeption in den Pastoralbriefen. Göttingen: Vandenhoeck \& Ruprecht.

HAGENBICHLER, E. 1992. Bescheidenheitstopos. (In Ueding, G., ed. Historisches Wörterbuch der Rhetorik. TI. 1. Darmstadt: Wissenschaftliche Buchgesellschaft. cols. 1491-1495.)

HOLMES, M.W., ed. 2007. The apostolic fathers: Greek texts and English translations. Grand Rapids: Eerdmans.

HÜBNER, R. 1997. Thesen zur Echtheit und Datierung der sieben Briefe des Ignatius von Antiochien. Zeitschrift für Antikes Christentum, 1:44-72.

IRENAEUS. 2001. Adversus Haereses: gegen die Häresien. Vol. 5. Trans. and introd. by N. Brox. Freiburg: Herder.

LAMPE, G.W.H. 1961. A Patristic Greek Lexicon. Oxford: Oxford University Press.

LIGHTFOOT, J.B. 1889a. The apostolic fathers. Vol. 2(1). London: Macmillan.

LIGHTFOOT, J.B. 1889b. The apostolic fathers. Vol. 2(2). London: Macmillan. 
LÖHR, H. 2009. Die Briefe des Ignatius von Antiochien. (In Pratscher, W., ed. Die Apostolischen Väter: eine Einleitung. Göttingen: Vandenhoeck \& Ruprecht. S. 104-129.)

LUCIAN. 1936. Lexiphanes. (In Harmon, A.M., ed. and trans. Lucian. London: Heinemann. p. 291-328.) (Loeb Classical Library, vol. 5.)

MEINHOLD, P. 1979. Schweigende Bischöfe: die Gegensätze in den kleinasiatischen Gemeinden nach den Ignatianen. (In Meinhold, P. Studien zu Ignatius von Antiochien. Wiesbaden: Steiner. S. 19-36.)

MOULTON, J.H. \& MULLIGAN, G. 1930. The vocabulary of the New Testament. London: Hodder \& Stoughton.

NORDEN, E. 1915. Die Antike Kunstprosa vom 6. Jahrhundert v.Chr. bis in die Zeit der Renaissance. Vol. 2. 3. Ed. Leipzig: Teubner.

PERLER, O. 1949. Das 4. Makkabäerbuch, Ignatius von Antiochien und die ältesten Märtyrerberichte. Rivista di archeologia Cristiana, 25:47-72.

PREUSCHEN, E. 1910. Analecta: kürzere Texte zur Geschichte der alten Kirche und des Kanons. Vol. 2. 2. Ed. Tübingen: Mohr Siebeck.

RIESENFELD, H. 1961. Reflections on the style and the theology of St. Ignatius of Antioch. Texte und Untersuchungen, 79:312-322.

ROBERTS, A. \& DONALDSON, J. 1973. The apostolic fathers - Justin Martyr Irenaeus. Grand Rapids: Eerdmans. (The Ante-Nicene Fathers, repr.)

SCHMITHALS; W. 2009. Zu Ignatius von Antiochien. Zeitschrift für antikes Christentum, 13(2):181-203.

SCHOEDEL, W.R. 1985. Ignatius of Antioch: a commentary on the letters of Ignatius of Antioch. Philadelphia: Fortress.

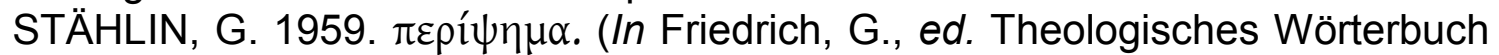
zum Neuen Testament. Vol. 6. Stuttgart: Kohlhammer. S. 83-92.)

STOOPS, R.F. 1987. If I suffer ...: epistolary authority in Ignatius of Antioch. Harvard theological review, 80:161-178.

TERTULLIAN. 1954. De Baptismo. (In Borleffs, J.G. Ph., ed. Tertulliani Opera. Pars 1. Turnhout: Brepols. p. 275-295.)

TERTULLIAN. 1992. Apologeticum: Verteidigung des Christentums - Lateinisch und Deutsch. Ed. and trans. by C. Becker. München: Kösel.

THESAURUS LINGUAE GRAECAE. 2010. Thesaurus linguae Graecae digital library. Irvine: University of California Press. http://www.tlg.uci.edu/ Date of access: 1 Apr. 2010.

TLG see THESAURUS LINGUAE GRAECAE

TREVETT, C. 1989. Ignatius "To the Romans" and 1 Clement 54-56. Vigiliae Christianae, 43:35-52.

UEBELE, W. 2001. Viele Verführer sind in die Welt ausgegangen: die Gegner in den Briefen des Ignatius von Antiochien und in den Johannesbriefen. Stuttgart: Kohlhammer. (Beiträge zur Wissenschaft vom Alten und Neuen Testament 151.)

VIELHAUER, Ph. 1975. Geschichte der urchristlichen Literatur: Einleitung in das Neue Testament, die Apokryphen und die Apostolischen Väter. Berlin: De Gruyter.

VON CAMPENHAUSEN, H. 1972. Das Bekenntnis im Urchristentum. Zeitschrift für die neutestamentliche Wissenschaft, 63:210-253.

ZAHN, Th. 1873. Ignatius von Antiochien. Gotha: Perthes. 


\section{Key concepts:}

Ignatius of Antioch

martyrdom

pragmatics

ransom

sacrifice

Kernbegrippe:

Ignatius van Antiogië

losprys

martelaarskap

opoffering

pragmatiek 
